\title{
IDENTIFICATION AND COMPARISON STUDY OF MARKETING STUDENTS ETHICAL SENSITIVITY
}

\author{
Tony Wijaya ${ }^{1 *}$, Agung Utama ${ }^{2}$, Nurhadi ${ }^{3}$, and Andreas M Kuncoro ${ }^{4}$ \\ 1,2,3,4 Universitas Negeri Yogyakarta, Yogyakarta
}

\begin{abstract}
The research aimed to identify and compare the ethical sensitivity level of marketing student. This research is descriptive-comparative using primary data. Sources of data in the study is a student of marketing management. The study used a saturated sample of all students who are still active (3 batches). Data collection techniques are surveys using questionnaires. Data analysis techniques in this study using descriptive statistics and analysis of variance. Based on the result of the research, it can be concluded that there is a significant difference in students' ethical sensitivity in $2^{\text {nd }}, 4^{\text {th }}$ and $6^{\text {th }}$ semesters significantly. $6^{\text {th }}$-semester students have better ethical sensitivity than $4^{\text {th }}$ and $2^{\text {nd }}$ semester. $4^{\text {th }}$-semester students have better ethical sensitivity than $2^{\text {nd }}$ semester.
\end{abstract}

Keywords: ethical sensitivity, marketing students, semester

\section{INTRODUCTION}

Businesses in Indonesia will face increasingly severe challenges in the future, so there is a need for work professionalism. The professionalism of a profession is manifested in ethical attitudes and actions. Ethical attitudes and actions are crucial to the position of businesspeople in society. The problem of business ethics is increasing not only in Indonesia but also in other countries including in developed countries. This is demonstrated by surveys conducted by Sales \& Marketing Management in a number of marketing managers who commit ethical violations (Roman \& Munuera, 2005). Attention to ethical issues is inseparable from the growing world of business as a result of development. Increasing business activity both at home and abroad has created new challenges, namely the demands of ethical practices, which are also the demands of business life in many countries around the world (Bertens, 2000).

Global economic transparency demands ethical business practices. Therefore, ethics is needed in business, because unethical business practices can reduce productivity and curb efficiency (Kartasasmita, 1997). Marketing is allegedly the most unethical business function and many marketing practices have been criticized (Laezniak, 1999). Another impact of unethical marketing behavior is the risk the company loses its customers (Roman and Munuera, 2005). Economic progress encourages the emergence of new business actors that lead to business competition. All these businesses seek to gain the most profit. Sometimes in order to achieve that goal, all efforts and actions are carried out even if the businessperson must take actions that ignore the moral dimensions and business ethics themselves, including ethics in product

* Corresponding author. Email address: tony@ uny.ac.id 
marketing. To anticipate this, it is necessary to identify ethical factors. Ethics is a fundamental concept for business. Awareness of the importance of this is precisely the case when various counter-ethical cases occur, both in certain professions and in general business.

Business education plays a fundamental role in positioning ethical behavior (Ermasofa et al., 2017). Ethics is a fundamental concept for the field of cultivation. Ethical paradigms provide principles and assumptions which handily overlay the multitude of variables a business person needs to consider when processing decisions and encountering dilemmas, regardless of their level of intensity (Lovett \& Woolard, 2016). Marketers' ethical behavior and actions will have an impact on consumers and the environment. The problems of marketing ethics are part of marketing research topics such as those conducted by Roman and Munuera (2005), Abratt \& Penman (2002), Schwepker (2003), Yoo \& Donthu (2002), Singhapakdi (2004), and Singhapakdi et al (2000a ; 2000b). Ethical issues should not occur if every marketer has the knowledge, understanding, and applying ethics adequately in the execution of his work. As an implementation of the increasingly widespread expectation of ethical issues among practitioners and academics of ethical education, the presence of subjects with moral and ethical teachings is very relevant to be conveyed to learners. Regardless of how it exists, ethical education has been recognized as having an important role in business development. The American Assembly of Collegiate School of Business (AACSB) as one of the accrediting agencies in America also posits the importance of ethics in the business program curriculum (Shannon \& Berl, 1997). The 1986 American Accounting Association's (AAA) through the Bedford Committee has emphasized the need to include studies on ethical issues in education. It also reveals that the National Commission on Fraudulent Financial Reporting through the Treadway Commission (1987) recommends to further expand the scope of ethics in education. Therefore, it is important for higher education to respond by incorporating or integrating ethics into the curriculum or needing to extend its scope within the existing curriculum.

Radtke (2000) states that ethical education is based on a premise that moral development can be enhanced through the educational process. This is corroborated by various ethical researches such as the identification of ethical educational goals; ethical issues and the need to access ethical teaching outcomes. The study of ethics has been widely practiced both overseas and domestically (Ameen et al., 1996; Radtke, 2000; Rustiana, 2003). Subjects who become respondents vary from professional group to group of students. The results of these researchers varied, with the finding that there were differences in ethics among the various groups and the opposite findings. Rustiana (2003) found differences in ethical sensitivity in male and female students. Mahfoedz (1999) found no ethical differences between junior and senior students differed from those of Stevens et al. (1993) who found a difference in ethical orientation between junior and senior students. Yoo \& Donthu (2002) found a learning relationship with ethical behavior in marketing.

In Indonesia, the existence of courses containing ethics content is inseparable from the mission of higher education as a higher education subsystem, which is not only responsible for teaching business science (science transformation) to the students but also responsible to educate students to have personality intact as human beings. Education makes people become more 


\section{IDENTIFICATION AND COMPARISON STUDY OF MARKETING STUDENTS ETHICAL SENSITIVITY}

ethically sensitive and are able to argue in ethical matter even though knowledgeable persons are not always ethical (Suwardi et al., 2014). The world of higher education has a great influence on student ethics behavior. The world of good education will encourage students to be business candidates who have a professional attitude and are based on moral and ethical standards. As a producer of energy or business to business and business, universities have a very strategic role to deliver and prepare the students to be professional candidates who have good ethical values. Ethics has an important role for marketing students as prospective marketing executives or marketing practitioners in the future and needs to be equipped with an ethical outline in the marketing profession (Yoo \& Donthu, 2002).

Ratdke (2000) points out the importance of detecting students' ethical behavior as early as to prevent unethical behavior through the scope or content of the ethics curriculum in the course. Studies yield interesting results regarding certain factors that influence the ethicality of business students and may impact the effectiveness of business ethics instruction (Wang \& Calvano, 2015). One attempt to detect ethical behavior is to identify through student sensitivity. Ethical inclusiveness is the description or proxy of the student's ethical actions after graduation. Sensitivity is a feature of action that detects the possibility of graduates in ethical behavior. If the student has behaved unethically then the possibility after graduation will have a tendency to behave unethically as well. This research seeks to determine the ethical sensitivity of marketing students as a consideration of the importance of ethical content in the marketing curriculum either explicitly or implicitly. The results of research show that the learning outcomes are profound and directly relevant to undergraduate curricular (Ahmed et al., 2017). The problem formulation is spelled out specifically as follows; how does the comparison of ethical sensitivity rate to the marketing student based on the semester level?

\section{LITERATURE STUDY}

Dellaportas et al., (2011) describe ethical sensitivity as "... the way an individual signifies the ethical situation and consequences of one's actions against others". According to Dellaportas et al., (2011), students' ethical sensitivity is one of the essential requirements for realizing ethical issues and raising future awareness to understand the possible impact of unethical problems on others. Business research is focused on making decisions and behaving ethically. However, an important factor in ethical judgment and behavior is the consciousness of individuals that they are moral agents. The ability to recognize ethical or moral values in a decision is what is called ethical sensitivity.

Decisions or actions related to moral matters must have consequences for others and should involve choice or willingness to choose from the decision maker. This definition has a broad sense because decisions often have consequences for others and the willingness to choose is almost always a gift, even though those choices are often at great risk. In some cases, many decisions are judged as moral decisions simply because they have moral content, but they are not.

Ethical sensitivity is the ability of students to realize ethical or moral values in an ethical decision (Ameen et al., 1996; Rustiana, 2003). The ethical sensitivity in this study is related to the academic activities of the students 
during the process of studying the lectures and reflected in the academic acts that have an impact on ethical behavior after becoming a businessperson. Ratdke (2000) argues that ethical sensitivity is a description or proxy of the students' ethical actions after graduation. Sensitivity is a feature of action that detects the possibility of graduates in ethical behavior. If as a prospective business actor, the student has behaved unethically then the possibility after graduation will behave unethically. This needs to be detected early on as a starting point to prevent unethical behavior through the scope or content of the ethics curriculum in the course, so as a potential business actor capable of competing and acting professionally.

Ethical decisions are complicated to judge primarily because the existing rules are not perfect as a means of ethical decisions. Often what happens is a legal but not always ethical decision. This biased state often leads to ethical problems. Ethical sensitivity of the students in the form of ethical considerations (Rustiana, 2003) while doing tasks, exams and assessments such as looking at other student exam answers, preparing notes for copying, borrowing reports or other papers for diplagiat, asking others to write or make papers, from others but without mentioning the source of the reference in the presentation of the report, before the exam asks questions on the class or parallel colleagues, asks answers to friends, exchanges test answers, writes case analysis reports or papers for other students, lies to lecturers to postpone exams reporting lecturer appraisal errors that benefit the student, copying other people's paper at home, not participating in group work on duty but can of equal value, visiting learning from other people's records without their permission, visiting lecturers after the exam in the hope of getting more value well, doing the exam for mahasi other students, get a copy of the exam before taking the exam, do the test before the time when the lecturer's instructions forbid it, give exam answers to other students during the exam, pay someone else to do the task or paper, arrange a seat in order to cheat, and bribe or threaten other students or lecturers to increase the value of the course.

\section{Research Hypothesis}

Ha: There is a significant difference in the degree of ethical sensitivity to students in the field of marketing campus Wates based on the level of the semester

\section{RESEARCH METHODOLOGY Types of research}

The type of this research is descriptive-quantitative. The orientation of this research is positivistic and in the process of collecting data is a survey.

\section{Operational Definition and Variable Measurement}

Variable in this research is interdependency that is ethical sensitivity. The operational definition relating to the meaning of all the variables used in this fieldwork is described and described as follows:

In this study, ethical sensitivity is the ability of students to realize ethical or moral values in an ethical decision (Ameen et al., 1996; Rustiana, 2003). Ethical sensitivity is measured (Ratdke, 2000) with student attitudes in terms of performing assignments, exams and judgments in the form of viewing other student exam answers, borrowing reports or other people's papers for example, asking others to write or make papers, writing ideas from others without mentioning the source of reference in the presentation of the report, writing a 


\section{IDENTIFICATION AND COMPARISON STUDY OF MARKETING STUDENTS ETHICAL SENSITIVITY}

case analysis report or paper for other students, their reasons for the lecturer to postpone the assignment, preparing the note to be copied, before the exam to ask questions on the class or colleagues palalel, request answers to friends, exchanged test answers , copying other peoples' assignments, not participating in group work on assignments, using paper on the internet, paying other people doing paperwork, looking at other people's records without their permission, doing exams for other students, arranging seats to cheat, get a copy of the exam before taking the exam, do so al the time-honored exam when the lecturer's instructions forbid it, giving the exam answers to the other students during the exam, not reporting the lecturer's misstatement in favor of the student, facing the lecturer after the exam in hopes of obtaining better grades, requesting value waivers, giving gifts with the aim of getting good grades. The instruments in this study were adapted from previous studies. The data rate of research variables collected in the form of score data range (interval) or use interval scale that is range 1-5.

\section{Types and Data Sources}

This study used primary data collected using a questionnaire on ethical sensitivity. Measurement of ethical sensitivity using a questionnaire adapted from Ratdke (2000).

\section{Test Instruments}

The instrument test in this research consisted of validity and reliability test. Validity test in this research use corrected aitem total correlation value. An item is said to be valid if it has a significance value $>0.05$ or greater $r$-table. Reliability testing using Cronbach Alpha to indicate the extent to which a tool can be trusted to measure an object, the coefficient alpha is approaching 1 means the question items in the coefficient more reliable. A variable is considered reliable if the Alpha coefficient is greater than 0.7 (now, 1992). The result of validity test shows corrected total correlation value of 0.349-0.906 with a significance level $<0,05$ which means that all item is valid. An Alpha coefficient of $0.954>0.7$ which means that ethical sensitivity variables are categorized reliable.

\section{Population and Sample}

The research population used as sample source is the marketing student of UNY. The sampling technique using non-probability technique with purposive sampling method, and chosen is a student of marketing management in Universitas Negeri Yogyakarta semester $2^{\text {nd }}, 4^{\text {th }}$ and $6^{\text {th }}$

\section{Data analysis technique}

The type of this research approach is descriptive. Data were analyzed using descriptive statistic and ANOVA.

\section{RESULT}

\section{Descriptive Analysis}

Descriptive analysis is used in analyzing students' ethical sensitivity. Based on the descriptive analysis, it can be seen the average data of ethical sensitivity of students in each group (semester) as follows: 


\section{IDENTIFICATION AND COMPARISON STUDY OF MARKETING STUDENTS ETHICAL SENSITIVITY}

significantly which shows an F-count value of 1349.665 with a significance of 0.000 .

\section{DISCUSSION}

The findings of this study are consistent with the results of Yulianty and Fitriany (2005) that found that the final semester students tended to be ethical compared to the students of the first semester. This reinforces the notion that ethical content in the curriculum contributes to students' ethical behavior. The content of the ethics curriculum in the learning process in marketing encourages students to consider the ethical orientation in making decisions. Evaluation and belief that ethical actions tend to have better and longer-term impacts (long term relationship). Shannon \& Berl (1997) also identified that business students who follow ethical courses have a tendency to act more ethically related to ethical issues in marketing. Yoo \& Donthu (2002) also found there was a significant relationship between formal and informal education with the tendency of students to behave ethically.

Theoretically, the explanation of purchasing behavior refers to a general concept of behavior that can be explained through an approach involving the cognitive and environmental aspects which are then referred to as cognitive social theory (Santrock, 2005). The cognitive social view proposed by Bandura (2001) explains that behavior as a response to a stimulus is largely determined by the state of the stimulus and the individual and the role of the environment. This formulation is no different from Lewin's formulation that behavior is the relationship between the environment and organism. The relationship is not yet clear so Bandura is clarified with interactional relations. An interactional relationship in question is the relationship behavior with the environment and personal aspects. This formulation addresses the limitations of cognitive views that use stimulus-organism-response formulation (S-O-R).

The response stimulus relationship does not take place automatically but the individual plays a decisive role, especially an ethically oriented action. A response is a function of stimulus and organism with the formulation of interaction between behavior, personal (cognitive) and environmental aspects. Learning ethics through stimulus will generate attitudes and interests to behave ethically. Individuals behave in making decisions in solving their problems (needs and wants). Individuals are involved in the learning process to solve the problem. Cognition learning emphasizes the thought process involving ethical knowledge. The cognitive social approach is more appropriate to explain the behavior of individuals who have high involvement in decision making. Individuals use knowledge in selecting and selecting decisions based on information they have. In addition, knowledge about the benefits and impacts of behavior is required.

\section{CONCLUSIONS}

Based on the above discussion it can be concluded that thoroughly there is a difference of student ethical sensitivity $2^{\text {nd }}, 4^{\text {th }}$ and $6^{\text {th }}$-semesters significantly. $6^{\text {th }}$-semester students have better ethical sensitivity than $4^{\text {th }}$ and $2^{\text {nd }}$-semester. $4^{\text {th }}$-semester students have better ethical sensitivity than $2^{\text {nd }}$ semester.

Based on the findings and conclusions in this study can be given some suggestions of the importance of ethical content required in the scope of the field of marketing. Consideration of ethical contents in the course of marketing 
is expected to encourage students to have good ethical sensitivity so that in marketing practices are able to behave ethically. There are several factors that are not researched like gender, experience, and age (Carbo et al., 2016). Future research can intend to investigate whether potential differences in such perceptions depend on previous business ethics courses taken, gender, and age of students.

\section{References}

Abratt, R., \& Penman, N. (2002). Understanding factors affecting salespeople's perceptions of ethical behavior in south africa, Journal of Business Ethics, 35, pp. 269-80.

Adams, L.B., Malane,L.F., \& James, W. Jr. (1994). Auditing: ethical reasoning in confidentiality decisions, The CPA Journal Online. Retrieved from http://archives.cpajournal.com/old/15611655.htm

Ahmed, A., johnsom, J, A., \& Ackers, H. (2017). Student learning on ethical educational placements. Part of book: The Ethics of Educational Healthcare Placements in Low and Middle Income Countries, pp. 47-82

Ameen, J.C., Gulfrey., \& McMillan, J,J. (1996). Gender differences in determining the ethical sensitivity of future accounting profesionals, Journal of Business Ethics. 15, pp 591-597

Bandura, A. (2001). Social cognitive theory: An agentic perspective. Annual review of psychology Palo Alto: Annual Reviews, Inc. 52, pp. 1-26.

Bertens, K. (2000). Pengantar Etika Bisnis, Edisi Keenam, Yogyakarta: Kanisius

Borkowski, S., \& Ugras, Y. (1992). The ethical attitudes of students as a function of age, sex and experience, Journal of Business Ethics, 11, pp 961-979.

Carbo, T, G., Mas, S, E., \& Oltra, V. (2016). Accounting ethics in unfriendly environments: The educational challenge, Journal of Business Ethics, 135, pp.161 - 175

Chua, F.C., M.H.B. Perera, \& M.R. Mathews. (1994). Integration of ethics into tertiary accounting programmes in new zealand and australia. Dalam Accounting Education for the $21^{\text {st }}$ Century: the Global Challenge, Edited by Jane O. Burns dan Belvesd E.Needles Jr., Edition 1.Sn: International Association for Accounting Education and Research.

Glover, S,H., Bumpus, M, A., Sharp, G, F., \& Munchus, G, A. (2002). Gender differences in ethical decision making. Women in Management Review. 17, 217-227.

Ericson, E, H. (1987). The Human Life Cycle, in S Schlein (ed). New York: Norton.

Ermasova, N., Wagner, S., \& Nguyen, L, D. (2016). The impact of education, diversity, professional development and age on personal business ethics of business students in Russia, Journal of Management Development, 36 (3), pp.410 - 426 
Kartasasmita, G. (1997). Etika dunia usaha atau etika bisnis dalam pembangunan. Lembaga Studi dan Pengembangan Etika Usaha Indonesia. Jakarta, 25 Agustus.

Kohlberg, L. (1984). The Psychology of Moral Development: The Nature and Validity of Moral Stages. Harper \& Row

Ludigdo \& Machfoedz., M. (1999). Persepsi Akuntan dan Mahasiswa tentang Etika Bisnis. Jurnal Riset Akuntansi Indonesia, 2(1)

Machfoedz, M. (1999). Studi persepsi mahasiswa terhadap profesionalisme dosen akuntansi perguruan tinggi. Jurnal Akuntansi dan Auditing Indonesia, 3(1).

Madjid, N. (1992). Ajaran Nilai Etis Dalam Kitab Suci dan Relevansinya Bagi Kehidupan Modern. Dalam Islam Doktrin dan Peradaban: Sebuah Telaah Kritis tentang Masalah Keimanan, Kemanusiaan, dan Kemodernan. Yayasan Wakaf Paramadina, Jakarta, Desember.

Radtke, R.R. (2000). The effect of gender and setting on accountants: Ethically sensitive decisions. Journal of Business Ethics. 24(4), pp 299-312

Roman, S., \& Munuera, J, L. (2005). Determinants and Consequences of Ethical Behaviour: An Empirical Study Of Slespeople. European Journal of Marketing,39 (5-6). Pp 473-495

Rustiana. (2003). Studi Empiris novice accountant: Tinjauan Gender, Jurnal Studi Bisnis. 1 (2).

Santrock, J.W. (2005). Psychology. McGraw-Hill Book Company, Inc:New York

Schwepker, C.H. (2003). An exploratory investigation of the relationship between ethical conflict and salesperson performance, Journal of Business \& Industrial Marketing, 18 (4/5), pp.435 - 446

Schwepker, C.H. (2001). Ethical climates relationship to job satisfaction, organizational commitment, and turnover intention in the salesforce, Journal of Business Research, 54, pp. 39-54.

Singhapakdi, A., Marta, J., Rallapalli, K.C., \& Rao, C.P. (2000a). Toward an understanding of religiousness and marketing ethics : An empirical study, Journal of Business Ethics, 27(4), pp.305-319.

Singhapakdi, A., Salyachivin, S., Virakul, B., \& Veerayangkur, V. (2000b), Some important factors underlying ethical decision making of managers in Thailand, Journal of Business Ethics, 27(3), pp.271-284.

Singhapakdi, A. (2004). Important factors underlying ethical intentions of students: Implications for marketing education, Journal of Marketing Education, 26(3), pp.261-270

Stevens, Robert E., OJ. Harris \& Williamson. (1993). A Comparison of ethical evaluations of business school faculty and students: A pilot study, Journal of Business Ethics. 12 
Suseno, F, M. (1997). Etika Dasar. Penerbit Kanisius, Yogyakarta

Suwardi, E., Artiningsih, A., \& Novmawan, M, R. (2014). Student perception in business ethics, Journal of Indonesian Economy \& Business, 29 (3), pp. $251-258$

Wang, C, L., \& Calvano, R. (2015). Is business ethics education effective? An analysis of gender, personal ethical perspectives, and moral judgment, Journal of Business Ethics, 126, pp.591 - 602

Yoo, B., \& Donthu, N. (2002). The effects of marketing education and individual cultural values on marketing ethics of student". Journal of Marketing Education. 24 (2). pp 92-103

Yulianty \& Fitriany. (2005).Persepsi mahasiswa akuntansi terhadap etika penyusunan laporan keuangan. Simposium Nasional Akuntansi VIII. 1516 September 2005. 